\title{
The Influence of Organizational Culture and Work Motivation on the Performance of Physical Education Teachers in Medan High Schools
}

\author{
Mesnan \\ Universitas Negeri Medan, Indonesia \\ mesnanyana@gmail.com
}

\begin{abstract}
The purpose of this study was to find and study: (1) the performance model of Physical Education teachers which is built based on the associative causal relationship between exogenous variables and endogenous variables. This research was conducted at Senior High Schools in Medan, involving 148 Physical Education teachers as respondents. For data collection, it was done using a questionnaire with five answer choices. The sampling technique used is proportional random sampling. The instrument used was tested first on respondents outside the sample to obtain valid and reliable instruments. The validity test uses Product Moment Correlation, while to test its reliability the Alpha formula from Cronbach. Before testing the hypothesis, the Requirements Analysis test is calculated including: data normality test and regression linearity test. Meanwhile, to test its reliability with the Alpha formula from Cronbach. The results showed (1) the Physical Education Teacher Performance Model (2) Organizational Culture has a positive direct effect on Job Satisfaction, (3) Transformational Leadership has a positive direct effect on Job Satisfaction, (4) Organizational Culture has a positive direct effect on Work Motivation, (5) ) Transformational Leadership has a positive direct effect on Work Motivation, (6) Organizational Culture has a positive direct effect on performance, (7) Transformational Leadership has a positive direct effect on performance, (8) Job Satisfaction has a positive direct effect on Performance, (9) Job Motivation has a direct effect on Performance. Positive on performance.Based on the acceptance of research hypotheses, it is found a theoretical model or fixed model that describes the structure of the causal relationship between organizational culture variables, transformational leadership, job satisfaction, work motivation, and the performance of high school Physical Education teachers in Medan City.
\end{abstract}

Keywords

organizational culture; transformational leadership; job satisfaction; work motivation; performance

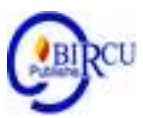

\section{Introduction}

According to Law no. 20 of 2003 article 1, Education is a conscious and planned effort to create an atmosphere of learning and the learning process so that students actively develop their potential to have religious spiritual strength, self-control, personality, intelligence, noble character, and skills needed by themselves, society, nation and state. The potential development of students is carried out both at home and in educational institutions. The potential of qualified students is expected to be able to face global competition. 
The special characteristics of education seen from the form of activities illustrate that education is a form of learning experience in life. Education takes place in line with the demands of development that continues to progress in various patterns, models and institutions and uses strategies to obtain the required quality. Education can also occur as a conscious human effort which aims to make beings who continue to progress in thinking. Education itself occurs anywhere and with anyone, often divided into formal and non-formal education.

According to Mulyasa (2005: 65) "the existing education has not been able to produce human resources in accordance with community development and development needs, although the current conditions are not entirely the fault of education". Human resources in schools in improving the quality of education are certainly mostly held by a teacher. Teacher competence has been stated in Law No. 14 of 2005 article 1 paragraph (1) on teachers and lecturers, which states that: "teachers are professional educators with the main task of educating, teaching, guiding, directing, training, assessing, and evaluating students at Early childhood education paths of formal education, basic education, and secondary education ".

Teachers in carrying out their duties are required to always improve the quality of their performance in a professional manner so that the learning objectives that have been determined can be achieved. In this study, the teacher whose performance was seen was a physical education teacher (Physical Education), so that all problems in learning that would be discussed in this case were problems in Physical Education learning.

Many problems occur in the physical education learning process in senior high schools (SMA). Problem Physical education is not only how the process of increasing the effectiveness of teaching and learning to achieve educational goals, but in it also contains several demands for changes in the cognitive, affective and psychomotor domains at the individual micro level. The effectiveness of the educational process is not only influenced by physical, biological and psychological aspects, but also from aspects of the geographical environment. That is why the provision of learning experiences that contain educational values, the implementation of approaches and learning models that are compatible with the substance of the teaching assignment and several other learning resources must adjust to the demographics according to the circumstances of the school. The physical education learning process in upper-level schools is of course not only related to practice in the field,

Mens there in corpore sanois a very well-known slogan which means that a healthy mind resides in a strong body. This means that when we can control our thoughts, of course we have a strong body. This means, in this physical education, we not only get knowledge, but also invite us to have a healthy or strong body. The real results expected from Physical Education are developments which include physical, mental, emotional, social and moral aspects. Many experts believe that physical education is the most appropriate vehicle for shaping the whole human being.

The problem faced by physical education today is the change in cultural values. The change is in the form of movement habits in Physical Education, because physical education is synonymous with fun learning because students are invited to go directly to the field and move pleasantly. However, the habit of moving has changed a lot and is replaced by a silent lifestyle. Its situation is replaced by a theory which is actually also important in learning, but if this is not accompanied by direct practice, it will certainly diminish the value of physical education lessons itself.

Physical education teachers should be well aware that the health of their students is also their responsibility. This lifestyle shift, triggered byvarious conveniences in everyday life which are supported by changes in living standards, the use of communication technology and fully automated transportation so that among children whose nature as playing creatures (homo luden) is greatly reduced and tends to eliminate physical activity in various activities. 
Physical education should be able to foster a child's love for a healthy life and sweep physical activity properly. Students are expected to be able to exercise regularly every week. Of course this must be supported by adequate facilities and infrastructure at the school. This is confirmed in Article 42 paragraph 2 National Education Standards, it is explained that each educational unit is required to have a place to exercise, a place of worship, a place to play, a place to create, and other spaces / places needed to support an orderly and sustainable learning process.

The number of standard content items in the physical education curriculum is very large so that the focus is on the formation of motors skillnot maximal. In fact, if we look at Article 17 of the National Education Standards there is explained that "the curriculum is developed in accordance with the education unit, regional potential, / regional characteristics, the socioculture of the local community and students. So if the teacher understands this the teacher can present learning offerings that are in accordance with the characteristics of the child and the region.

However, the current condition greatly influences technological development. The development of increasingly advanced technology makes some people feel more lazy. Many things can be helped by these technological advances. For example, the activity of going up and down stairs can move the body, now it is replaced by a super practical lift. Therefore, WHO predicts that in 2020 as many as $73 \%$ of deaths will be caused by non-communicable diseases, or as much as $60 \%$ due to low physical fitness.

According to Law No. 14 of 2005, article 10 paragraphs 1 on Teachers and Lecturers, it is stated that teacher competence includes pedagogical competence, personality competence, social competence and professional competence obtained through professional education. The real conditions in the field show that the competence of teachers in SMA in Medan city is still low, where teacher competence is still quite far from the predetermined standard. This phenomenon is based on data sources from the North Sumatra Education Quality Assurance Institute (LPMP), the 2013 Teacher Competency Test (UKG) score for high school teachers was 53.635 on average with details of 55.48 for teachers and 51.79 for private teachers, and In 2014, the average UKG score was 56,355, with details of 57.81 for high school teachers and 54.90 for private high school teachers (Amelia, 2015: 95).

The problems mentioned above are closely related to the performance of human resources, namely Physical Education Teachers who must also be considered. The data above illustrates that the performance of a Physical Education teacher is also a factor in the success of student education in schools. Of course many people consider student health trivially, while health has something to do with the way students learn, their ability to understand learning, affect the concentration of students in the teaching and learning process and many others. For this reason, researchers are interested in examining whether the influence of Physical Education teacher performance in schools and what variables can increase or decrease the performance of Physical Education teachers in schools.

According to Sulistiyani, 2003: 223) says that "a person's performance is a combination of abilities, efforts and opportunities that can be assessed from the results of his work". So that many factors, both exogenous and endogenous, can contribute to teacher performance, in this case Physical Education teachers.

Teacher performance can increase and according to many factors AA Anwar Prabu Mangkunegara (2013: 116) states that performance factors consist of internal factors and external factors. Internal factors (dispositional) namely the factors associated with a person's characteristics. For example, someone's performance is good because they have high abilities and someone is the type of hard worker and does not have the feeling of giving up, while someone has low performance because that person has low abilities as well and that person 
does not have the effort to improve his attitude and hone his abilities. Furthermore, external factors, namely factors that affect a person's performance that come from the environment. Such as the behavior, attitudes and actions of subordinate colleagues or leaders, work facilities and organizational climate. These internal and external factors are the types of attributions that affect a person's performance.

One thing that can affect teacher performance is the organizational culture in which the teacher teaches. Borganizational culture is a cognitive framework consisting of attitudes, values, behavior norms and shared expectations felt by organizational members (Sudarmanto. 2009: 225). The organizational culture is much influenced by the school community because organizational culture is also an agreement that is agreed by the school community itself as the signs they run in the school. This organizational culture is part of the strength of the school community which is directly related to improving the performance of physical education teachers at SMA Koata Medan.

The next factor in this study is teacher work motivation. Mmotivation is a desire in a person that causes the person to act to achieve goals (Jackson, 2006: 115). With high work motivation it is expected that teacher performance will increase. The results showedteachers in SMA throughout Medan City have good teacher work motivation. Work motivation makes teachers have a better desire to work and be responsible for their work. Teacher work motivation is closely related to teacher performance. Where teacher performance is something that is closely related to teacher performance. Someone who has teacher performance is expected to have good work motivation too. Because teachers who are highly motivated at work will have good performance as well and vice versa.

\section{Review of Literatures}

\subsection{Teacher Performance}

Performance interpreted as the result of work or implementation of work tasks. According to August W. Smith, "performance is output derives from processes, humanor therwise", namely performance is the result of a process carried out by humans or performance is the result or output of a process. Performance is the result or overall success rate of a person during a certain period in carrying out a task when compared to various designs, such as work results, targets or goals or criteria that have been determined from the start and have been mutually agreed (Rivai, 2005: 88)

Performance is the result of a person's efforts that can be measured according to what is achieved by someone where the person works according to their abilities. In other words, what a person has achieved related to his / her day-to-day work can be called performance. Endin Nasruddin said that performance is defined as the results and achievements achieved by a person through his / her performance abilities (Nasruddin E. 2010: 238). In addition, performance according to As'ad (2005: 87) is a result of work achieved by a person in carrying out the tasks assigned to him based on his skills, experience and sincerity.

According to Susanto (2016: 176) Performance is the result of work or work performance of a person or organization with the appearance that performs, describes and produces something, both physical and non-physical in accordance with the instructions, functions and duties which are based on knowledge, attitudes, skills, and motivation.

According to Yani in Syardiansah (2020) performance is a result of work achieved by a person in carrying out the tasks assigned to him based on skill, experience and sincerity as well as time. However according to Kasmir (2016) that performance is the result of work and work behavior of a person in a period, usually 1 year. Then the performance can be measured by the ability to complete the tasks and responsibilities given. This means that in work contains 
elements of the standard that achievement must be met, so, for those who reach the standards set means good performance. While Fahmi (2016: 203) defines performance as the results obtained by an organization both the organization is profit oriented and non profit oriented

Based on the results of the expert's explanation above regarding the nature of physical education teacher performance, it can be concluded that basically the essence of performance is a picture of a teacher in completing his responsibilities in physical education both in motor, sensory and affective aspects which are summarized in physical education subjects in schools.

\subsection{Organizational Culture}

Nasution (2006: 249) argues that culture contains six main aspects, namely: (1) culture is a social construction of cultural elements, such as values, beliefs and understandings, shared by all group members, (2) culture provides guidance for its members in understanding an event, (3) culture contains habits or traditions, (4) in a culture, patterns of values, beliefs, hopes, understandings, and behaviors arise and develop over time, (5) culture directs behavior, habits , or tradition is the glue that unites an organization and ensures that its members behave in accordance with norms, and (6) the culture of each organization is unique.

In another section it is also stated that value has the following functions: (1) value as standard; (2) values as the basis for conflict resolution and decision making; (3) value as motivation; (4) values as a basis for adjustment; and (5) values as the basis for self-realization.

So, according to the above conclusions, culture is the values and patterns of behavior and ways of thinking of a person that adjusts to the place and conditions in which the individual is. So when someone is in an organization, there is a culture that applies to all members in it.

Attached culture is juxtaposed with the organization as values or rules developed in the organization. In Luthans' view, organizational culture is the norms and values that direct the behavior of organizational members. Each member will behave in accordance with the prevailing culture, in order to be accepted by the environment. Organizational culture is defined as a cognitive framework that contains attitudes, values, norms and shared expectations shared by organizational members. Organizational culture is related to the context of organizational development, meaning that culture is rooted in the history of the organization, is believed to be shared and is not easily manipulated directly.

Robbins (2003: 286) states that organizational culture is a system of shared meaning held by members that differentiates the organization from other organizations. This system of shared meaning, when examined more closely, is a set of major characteristics that the organization upholds. Kreitner and Kinicki define that organizational culture is an organizational glue that binds organizational members through values that are adhered to, symbolic tools, and social ideals to be achieved.

Organizational culture is a set of assumptions or systems of beliefs, values, and norms developed in organizations that serve as guidelines for behavior for its members to overcome the problem of external and internal adaptation. Organizational culture is a pattern of beliefs and organizational values that are believed and imbued by all members in doing work as an appropriate way to understand, think, and feel about related problems, so that it will become a value or rule within the organization. This will encourage members of the organization to work harder and create work motivation. (Mangkunegara in Arif, 2019)

According to Schott in West andTurner (2008: 65) who says that organizational culture includes emotional and psychological climate or atmosphere. This allows the organizational culture to include employee morale, attitudes and employee productivity levels (Turner. 2008: 371). Green Berg and Baron in Sudarmanto suggest that organizational culture is a cognitive framework consisting of attitudes, values, behavior norms and shared expectations felt by organizational members. 


\subsection{Work Motivation}

According to Nawawi (2003: 351) motivationis the desire in someone that encourages that person to take an action to achieve a goal. Meanwhile, according to Efendi (2000: 320) motivation can be defined as the factors that direct and encourage a person's behavior or desire to carry out an activity that is expressed in the form of hard or weak efforts. Furthermore, according to motivation is a psychological process of asking for direction, direction and establishing voluntary actions that lead to goals. Every company will always try to increase employee motivation in the hope that what the company's goals will be achieved (Kinicki, 2005: 248).

As for according to Mathis and Jackson (2006: 115) motivation is a desire in a person that causes the person to act to achieve goals. SadHasibuan states that motivation is what causes, channels, and supports human behavior so that they are willing to work hard and enthusiastically to achieve optimal results (Hasibuan. 2010: 121).

Motivation comes from the Latin word movere which means drive or driving force. Motivation in management is only aimed at human resources in general and in particular subordinates. According to Mangkunegara (2005), motivation is a process that plays a role in the intensity, direction, and duration of individual efforts towards achieving goals. According to Hasibuan (2007), motivation is the provision of a driving force that creates the excitement of one's work, so that they want to work together, work effectively and be integrated with all their efforts to achieve satisfaction. (Purba and Sudibjo, 2020)

Looking at the explanation from the experts above that motivation is the overall internal condition as well as external conditions that become a driving force so that someone wants to do a job according to expectations. Fulfilling these needs will create a strong impetus to move individuals to achieve goals. This implies that the greater the work motivation of the teacher, the greater the chance to achieve the educational goals set. So clearly motivation functions to encourage people to work, direct their work, and select their actions, to achieve the educational goals they set (Purwanto, 2011: 231).

\section{Research Methods}

This research can be classified as ex post facto research involving 148 physical education teachers in SMA Kota Medan. The method in data collection is used by providing a questionnaire with five answer choices. The sampling technique used was proportional random sampling. The instrument used was first tested outside the sample to ensure valid and reliable instruments. The validity test used the produc moment correlation, while the reliability test used Croncbach alpha. Before testing the hypothesis, the analysis prerequisite test is carried out including the normality test and the regression linearity test.

\section{Result and Discussion}

The research data description presents the average score, lowest score, highest score, range, mode, median and standard deviation. To make it easier to understand the research data, the data is also presented in the form of a frequency distribution and a histogram graph, a description of the variable data presented includes Organizational Culture data $\left(\mathrm{X}_{1}\right)$, Work Motivation (X2), (and Performance of Physical Education Teachers (X3) in Medan City in 2020. The summary of the results of the descriptive analysis is presented in table 4.1 below: 
Table 1. Summary of Calculation Results Descriptive Statistics of Research Data

\begin{tabular}{|l|r|r|r|}
\hline & $\begin{array}{c}\text { Organizational } \\
\text { culture } \\
(\mathrm{X} 1)\end{array}$ & $\begin{array}{c}\text { Motivation } \\
\text { Work } \\
(\mathrm{X} 2)\end{array}$ & $\begin{array}{r}\text { Teacher Performance } \\
(\mathrm{X} 3)\end{array}$ \\
\hline $\mathrm{N} \quad$ Valid & 148 & 148 & 148 \\
Mean & 0 & 0 & 0 \\
Median & 156.94 & 159.63 & 176.07 \\
Mode & 154.00 & 160.00 & 179.50 \\
Std. Deviation & $136 \mathrm{a}$ & 175 & 154 \\
Variance & 26,774 & 30,810 & 32,153 \\
Range & 716,874 & 949,228 & 1033,824 \\
Minimum & 129 & 131 & 133 \\
Maximum & 96 & 91 & 106 \\
Sum & 225 & 222 & 239 \\
\hline
\end{tabular}

Based on the descriptive data for organizational culture variables, it can be obtained that an average score of 156.936 is in the 4th inversion class with 35 respondents or $23.649 \%$. This means that out of the 148 respondents, there were 56 people or $37.84 \%$ who had scores below the average and 57 respondents or $38.51 \%$ who had scores above the average. The lowest score of empirical data is known to be 96 and the highest score is 225 and the average score of empirical data156,939; while the ideal maximum score is 225 and the ideal minimum score is 45 , so that the average ideal score is $1 / 2(225+45)=135$ and the ideal standard deviation is $1 / 6$ $(225-45)=30$. Thus based on the results of these calculations it is known that the average empirical score $(156,939)$ is higher than the average ideal score of $(135,000)$. When viewed from the trend level of the distribution of organizational culture data from 148 respondents, the answers from these respondents varied, namely that $12.84 \%$ of respondents stated that their organizational culture was good, as many as $70.27 \%$ of respondents stated that the organizational culture was sufficient, as many as $16.89 \%$ of respondents stated that their organizational culture was in the poor category. The distribution of organizational culture scores spreads from the lowest score of 99 to the highest score of 225. Thus it can be concluded that the respondents' scores on organizational culture tend to be sufficient. This still does not indicate a cognitive ability that can integrate educational resources in order to achieve predetermined educational goals. A conducive organizational culture is a prerequisite for the implementation of an effective teaching and learning process. A safe and orderly school environment, optimism and high expectations from the school community, school health and student-centered activities are examples of school culture that can foster student enthusiasm for learning. This is due to the organizational culture as one of the determinants of a teacher's success as an educator. In creating a good organizational culture,

Based on the data description for the physical education teacher work motivation variable, it shows that the average score of 159.628 is in the 5th interval class with 29 respondents or $19.594 \%$. This means that out of the 148 respondents, there were 72 people or $48.649 \%$ who had scores below the average and as many as 47 respondents or $31.757 \%$ who had scores above the average. The lowest score of empirical data is known to be 91 and the highest score is 222 and the average score of empirical data is 159.628. While the ideal maximum score is 225 and the ideal minimum score is 45 , so that the average ideal score is $1 / 2$ $(225+45)=135.00$ and the ideal standard deviation is $1 / 6(225-45)=30.00$. Thus the results of these calculations show that the average empirical score (159.628) is higher than the average ideal score of (135.00). The data collected from 45 statement items answered by 148 
respondents indicated that there were variations on several answer choices, namely indicating that as many as $8.78 \%$ of respondents stated that their work motivation was in the Good category, as many as $71.62 \%$ of respondents stated that their work motivation was in the Sufficient category, and $29.60 \%$ of respondents stated that their work motivation was in the category of Less. The distribution of empirical scores for the statement of work motivation of Physical Education teachers spreads between the lowest score of 91 to the highest score of 222 . It can be concluded that the respondents' scores on the motivation of the teachers of Physical Education for Senior High Schools in Medan are categorized as relatively moderate. This shows that the principal has not fully lived up to his job. Physical education teachers do not have work motivation a week so they cannot do work optimally.

Based on the data description of the physical education teacher performance variable data, it shows that the average score of 176.074 is in the 5th interval class with 34 respondents or $22.97 \%$. This means that out of the 148 respondents, there were 72 people or $48.65 \%$ who had scores below the average and as many as 42 respondents or $28.38 \%$ who had scores above the average. The lowest score of empirical data is known to be 106 and the highest score is 239 and the average score of empirical data is 176.074. While the ideal maximum score is 250 and the ideal minimum score is 50 , so that the average ideal score is $1 / 2(250+50)=150.00$ and the ideal standard deviation is $1 / 6(250-50)=33.33$. Thus, based on the results of these calculations, it is known that the average empirical score (176.074) is higher than the ideal average score of (150.00). Based on the research findings, the trend level of the data collected from 50 statement items answered by 148 respondents indicated that there were variations in several answer choices, namely showing that $5.41 \%$ of respondents stated that the performance of Physical Education teachers was in the Good category, as many as $72.97 \%$ of respondents indicated that Physical education teacher performance is in the Enough category, and as many as $21.62 \%$ of respondents stated that Physical Education teacher performance was in the Poor category and there were no respondents who stated that Physical Education teacher performance was in the low category. The distribution of empirical scores for teacher performance appraisal spreads between the lowest score of 106 to the highest score of 239. It can be concluded that the respondents' scores on the performance of Physical Education teachers tend to be Sufficient.

\section{Conclusion}

Organizational culture has a positive direct effect on the work motivation of Physical Education teachers in Medan City High Schools. In other words, the stronger the organizational culture, the higher the work motivation of Physical Education teachers in SMA Kota Medan.

Organizational culture has a positive direct effect on the work performance of Physical Education teachers in Medan high schools. In other words, the stronger the organizational culture, the higher the performance of Physical Education teachers in SMA Kota Medan.

Work motivation has a positive direct effect on the work performance of Physical Education teachers in SMA Medan. In other words, the higher the work motivation, the higher the performance of Physical Education teachers in SMA Kota Medan.

Based on the research results, it was found that organizational culture, transformational leadership, job satisfaction, and teacher work motivation have a direct effect on the performance of physical education teachers in SMA Kota Medan. This shows that physical education teacher performance can be improved if organizational culture, transformational leadership, job satisfaction, and work motivation are also improved. The findings in this study are expected to be used to add to the literature for relevant research in the future, especially research related to teacher performance. 


\section{References}

Ambar Teguh Sulistiyani. (2003). Manajemen dan Sumber Daya Manusia : Konsep Teori dan Pengembangan Dalam Konteks Organisasi Publik. Yogyakarta: Graha Ilmu. Hal. 223.

Amelia, A. (2015). Implementasi Supervisi Akademik Oleh Pengawas SMA Pada Guru Mata Pelajaran Bahasa Indonesia Di Kota Medan. Program Pascasarjana. Universitas Negeri Medan.

Arif, Syamsul. (2019). Influence of Leadership, Organizational Culture, Work Motivation, and Job Satisfaction of Performance Principles of Senior High School in Medan City. Budapest International Research and Critics Institute (BIRCI-Journal), 239-254.

As'ad, Moh. (2005). Psikologi Industri. Edisi Keempat. Yogjakarta. Liberty

A.A. Anwar Prabu Mangkunegara (2010). Evaluasi Kinerja SDM, PT.Refika Aditama, Bandung.Bangun, Wilson, 2012, Manajemen Sumber Daya Manusia, Erlangga, Bandung

Barnawi dan Mohammad Arifin. (2014). Kinerja Guru Profesional: Instrumen Pembinaan, Peningkatan dan Penilaian. Jogjakarta: Ar-Ruzz Media.

E. Mulyasa. (2005). Menjadi Guru Profesional Menciptakan Pembelajaran Kreatif dan Menyenangkan, Bandung: Remaja Rosda Karya

Hasibuan, Malayu, SP. (2017). Manajemen Sumber Daya Manusia Edisi Revisi. Jakarta: Bumi Aksara

Nawawi, Hadari. (2006). Evaluasi Dan Manajemen Kinerja Di Lingkungan Perusahaan Dan Industri. Yogyakarta: Gadjah Mada University Press

Purba, K and Sudibjo, K. The Effects Analysis of Transformational Leadership, Work Motivation and Compensation on Employee Performance in PT.Sago Nauli. Budapest International Research and Critics Institute-Journal (BIRCI-Journal). P. 1606-1617.

Riva'i, M. (2015). Administrasi dan Supervisi Pendidikan - Jilid 1. Bandung: Yenmars

Richard West dan Lynn H. Turner. (2008). Pengantar Teori Komunikasi: Analisis Dan Aplikasi. Terjemahan Maria Natalia Damayanti Maer. Jakarta: Salemba Humanika. Hal. 317.

Robert L. Mathis dan John H. Jackson. (2006). Human Resource Management: Manajemen Sumber Daya Manusia. Terjemahan Dian Angelia. Jakarta: Salemba Empat.

Robbins, P.S. (2006). Organizational Behavior, (9th Edition), New York : Prentice Hall International.

Robert Kreitner dan Angelo Kinicki. (2005). Perilaku Organisasi (Orgaizational Behavior). Jakarta: Salemba

Sudarmanto. (2009). Kinerja dan Pengembangan Kompetensi SDM. Yogyakarta: Pustaka Pelajar

Syardiansah, et al. (2020). The Effect of Job Satisfaction and Organizational Culture on Employee Performance of the Royal Hotel in East Aceh District. Budapest International Research and Critics Institute-Journal (BIRCI-Journal). P. 849-857 